Journal : JMMR (Jurnal Medicoeticolegal dan Manajemen Rumah Sakit), 9 (2): 127-134, August 2020

Website : http://journal.umy.ac.id/index.php/mrs

DOI $\quad$ : https://doi.org/10.18196/jmmr.92123

\title{
Impact of Work Environment and Work Stressing on The Job Satisfaction of Medical Record Officers
}

\author{
Atma Deharja ${ }^{1}$, Nonik Aisyah Rohman ${ }^{2}$, Rossalina Adi Wijayanti ${ }^{3}$ \\ ${ }^{1}$ Correspondence Author: atma_deharja@polije.ac.id \\ ${ }^{1}$ Medical Record StudyProgram, Health Department, Politeknik Negeri Jember, Indonesia \\ 2Magister Program of Public Health, University of Jember, Indonesia \\ 3Medical Record StudyProgram, Health Department, Politeknik Negeri Jember, Indonesia
}

I N D E X I N G

Keywords:

Job satisfaction;

Medical record;

Hospital;

\begin{abstract}
A B S T R AC T
Factors that influence the work satisfaction of medical record officer is the work environment and work stress. Uncomfortable work environment and work stressing with a lot of work demands make the staff will experience severe pressure. Based on the preliminary study on April 1st, 2018, it's found that seven officers who often absent (above 10\%), small workspace, awkward movement, inadequate facilities, double jobs, and double shifts that made 10 out of 13 officers experience unenjoyable in their work. The purpose is to analyze the effect in the work environment and work stressing on the work satisfaction of medical record officers in the X Hospital. It is analytical with a cross-sectional approach using ordinal logistic regression and questionnaire as an instrument. The sample used is 13 medical record officers-the work environment and work stressing as independent variables and work satisfaction as dependent variables. The significance value of the work environment and work stress variable is 0.002 . It has a significance value $<\alpha(\mathrm{P}<0.05)$, proving that the work environment and work stressing have a significant effect on work satisfaction. This study's suggestions need to be the expansion of workspace, additional facilities, and officers to avoid double jobs and double shifts.
\end{abstract}

Kata kunci:

Kepuasan Kerja;

Rekam Medis;

Rumah Sakit;

Faktor yang mempengaruhi kepuasan kerja petugas rekam medis adalah lingkungan kerja dan stres kerja. Lingkungan kerja yang kurang nyaman dan stres kerja dengan tuntutan pekerjaan yang banyak membuat petugas akan mengalami tekanan yang berat. Berdasarkan hasil studi pendahuluan tanggal 1 April 2018, didapatkan 7 petugas yang sering tidak masuk tanpa keterangan (diatas 10\%), ruang lingkup kerja yang sempit, pergerakan alur kerja yang sulit, fasilitas yang kurang memadai, double job, dan double shift yang membuat 10 dari 13 petugas mengalami ketidaknyamanan dalam bekerja. Tujuan penelitian ini untuk menganalisis pengaruh lingkungan kerja dan stres kerja terhadap kepuasan kerja petugas rekam medis di Rumah Sakit X. Metode dalam penelitian ini adalah analitik dengan pendekatan cross sectional menggunakan uji regresi logistik ordinal dengan kuesioner sebagai instrumen penelitian. Sampel yang digunakan sebanyak 13 orang. Variabel lingkungan kerja dan stres kerja sebagai variabel bebas dan variabel kepuasan kerja sebagai variabel terikat. Nilai signifikansi variabel lingkungan kerja dan variabel stres kerja sebesar 0.002 dengan nilai signifikansi $<\alpha(P<0,05)$, membuktikan lingkungan kerja dan stres kerja berpengaruh signifikan terhadap kepuasan kerja. Saran dari penelitian ini perlu diadakannya perluasan ruang kerja, perlu adanya penambahan fasilitas dan petugas agar tidak adanya double job dan double shift.

(C) 2020 JMMR. All rights reserved

Article History: Received 2020-05-01; Revised 2020-07-25; Accepted 2020-08-12

\section{INTRODUCTION}

Medical Record unit consists of medical record officers who have function analyze, integrate, and collect information patient, arrange information for interest research, evaluation, and planning service health (Pormiki, 2010). Human Resource (HR) 
Management is the development, utilization, assessment, and management of members or groups for workers (Itika, 2011). The purpose of a medical record unit is needed HR management to influence the work satisfaction that could improve the performance of medical record officer (Aliga, 2015). Work satisfaction is a positive emotion seen in one's work experience (Shukla et al., 2016). The factors that could influence officer work satisfaction among the working environment and working stress.

The working environment is everything that can affect workers in carrying out the tasks, which consist of factor-sourced internal factors within the organization (Rut Manggiasih, 2014). Work stress is a feeling of distress experienced by employees in the face of work (Mangkunegara, 2014). Stress work is a condition of the tension that creates existence imbalance between physical and psychic, which affects emotion, process thought, and condition an employee (Chairizal et al., 2014). Arises stressed-out work because of incomprehension to work, because it is too many works or information (Organisation for Economic Co-operation and Development (OECD), 2012)

X Hospital is a type C hospital located on Jember Regency. X Regional Hospital has 77 non-health workers, and among them is medical record officers. The medical record officers at the X Hospital are 13 people consisting of 7 high school graduates, 1 of Diploma graduate, and 5 of Bachelor graduates consisting of original medical record graduates.

Several factors can reduce the level of satisfaction of medical record officers, which is marked by data absent from medical record officers. The attendance data of medical record officer from X Regional Hospital could be seen on the table.1:

Table. 1 The Attendance Medical Record Officer in The X Regional Hospital March-May 2018

\begin{tabular}{|c|c|c|c|c|c|c|c|c|c|c|}
\hline \multirow{3}{*}{ Respondent } & \multicolumn{6}{|c|}{ Month } & \multirow{2}{*}{\multicolumn{2}{|c|}{ Total }} & \multirow{3}{*}{$\begin{array}{c}\text { Total Number } \\
\text { of Working } \\
\text { Days }\end{array}$} & \multirow{3}{*}{$\begin{array}{c}\text { No Description } \\
\text { (A in \%) }\end{array}$} \\
\hline & \multicolumn{2}{|c|}{ March } & \multicolumn{2}{|c|}{ April } & \multicolumn{2}{|c|}{ May } & & & & \\
\hline & $\mathrm{I}$ & A & $\mathrm{I}$ & A & $\mathrm{I}$ & $\mathrm{A}$ & I & A & & \\
\hline Respondent 1 & 30 & 0 & 0 & 0 & 2 & 2 & 32 & 2 & 72 & 2.78 \\
\hline Respondent 2 & 0 & 2 & 0 & 2 & 0 & 0 & 0 & 4 & 72 & 5.56 \\
\hline Respondent 3 & 0 & 2 & 0 & 3 & 0 & 0 & 0 & 5 & 72 & 6.94 \\
\hline Respondent 4 & 0 & 5 & 0 & 3 & 0 & 5 & 0 & 8 & 72 & 11,11 \\
\hline Respondent 5 & 0 & 2 & 0 & 2 & 0 & 0 & 0 & 4 & 72 & 5.56 \\
\hline Respondent 6 & 0 & 2 & 0 & 4 & 0 & 5 & 0 & 11 & 72 & 15.28 \\
\hline Respondent 7 & 0 & 8 & 0 & 7 & 1 & 9 & 1 & 23 & 72 & 31.94 \\
\hline Respondent 8 & 0 & 6 & 0 & 10 & 0 & 9 & 0 & 25 & 72 & 34.72 \\
\hline Respondent 9 & 0 & 2 & 0 & 3 & 0 & 3 & 0 & 5 & 72 & 6.94 \\
\hline Respondent 10 & 0 & 7 & 0 & 8 & 3 & 6 & 3 & 21 & 72 & 29.17 \\
\hline Respondent 11 & 0 & 3 & 0 & 2 & 0 & 0 & 0 & 5 & 72 & 6.94 \\
\hline Respondent 12 & 0 & 10 & 0 & 10 & 1 & 8 & 0 & 28 & 72 & 38.89 \\
\hline Respondent 13 & 0 & 6 & 0 & 0 & 0 & 4 & 0 & 10 & 72 & 13.89 \\
\hline
\end{tabular}

Source: X Regional Hospital, 2019

Based on table.1 can be known that seven officers often do not enter without the information (percentage without the information is above 10\%). Plus, with a lack of supervision and lack of sanctions imposed related to attendance data so that officers record medical can with easy not enter work. The impact of lack of satisfaction officers is level high absenteeism (Singh et al., 2016). Attendance level top officials will harm continuity life and 
hospital productivity, so process achievement hospital aim can be hampered. Based on the preliminary research results, it is semi-structured interviews at the X Hospital on April $1^{\text {st }}$, 2018, from 13 officers, only three medical record officers felt comfortable working. In contrast, ten medical records officers are uncomfortable operation in terms of their work and working environment. Trouble in a job can cause employee work satisfaction is decline.

The inconvenience experienced by employees can be fatal, namely, a decrease in employee work satisfaction that affects employee performance at work (Aruan \& Fakhri, 2015). It is proven by the results of a study conducted by Laksmini (Laksmini et al., 2019); work satisfaction affects officers' performance by $73,3 \%$. The work environment also influences employee work satisfaction. It is proven by the results of research conducted by Oldemar (Oldemar, 2015), that the work environment affects employee satisfaction by 49.6\%. According to Robbins (Robbins \& Judge, 2014) urged that the work environment includes the scope of work and work facilities that can increase work satisfaction. Kepmenkes Number 1405 / Menkes / SK / XI / 2002 concerning Health Requirements for the Work Environment states that a good workspace design and adequate work facilities can prevent the occurrence of health problems in the work environment (Menteri Kesehatan Republik Indonesia, 2002).

In terms of the scope of work of medical record officers, the state of the room for officers and the number of doors is the right of access and still a problem for medical record officers. The state of the room for coding, reporting, and assembling officers is made into one place, causing officers to feel less comfortable carrying out work with small movements. The registration officer also feels uncomfortable because of the limited area of practice and difficulty in moving. Work stress also influences employee work satisfaction. It is proven by the results of research conducted by (Hapsari, 2017), that work stress affects employee satisfaction by $82.26 \%$. Work stress includes the demands of the task, the needs of the role, and the organization (Robbins \& Judge, 2014). According to the Republic of Indonesia Law Number 36 of 2009 article 26, the number of workers adjusted to workload can affect work stress (Indonesia, 2009).

In terms of task demands and role demands, medical records officers often complain about their work. In the outpatient registration and emergency registration section, medical record officers in doing their jobs always experience double jobs and double shifts. It can be seen in the outpatient registration section combined with inpatient registration along with the cashier to pay for the services and registration of the emergency room at the "X" Hospital combined with the inpatient registration as well as the cashier to pay for services. The employee for registering an emergency room with one person each day was also tasked with delivering the file to the filling room. The distance between the filling room and the emergency room was quite far. Based on the description, the researchers are interested in analyzing in terms of the influence of the work environment and working stress. This study aimed to examine the impact of the work environment and work stress on medical record officers' work satisfaction.

\section{RESEARCH METHOD}

The research deployed an analytic survey with a cross-sectional study as the data is collected once. The research was conducted at X Hospital. Data were collected from January 
- March 2019. The population in this study are all officer in the hospital medical record number of 13 and obtained until 1 as many as 13 people with a sampling technique that is a total sampling.

Data collection was conducted through a questionnaire. Data analysis was performed by an ordinal logistic regression study using SPSS. It aims to analyze the influence of independent variables included work environment and work stress towards the dependent variable called work satisfaction at X Hospital.

\section{RESULT AND DISCUSSION}

Management analysis of multivariate data is namely, dependency analysis. Dependency analysis functions to explain or predict dependent variables by using two or more independent variables (Yulianto et al., 2019). The result of a multivariate test that analyzes the effect of the work environment and works stress on work satisfaction of medical record officers in X Hospital could be seen in Table. 2 below:

Table.2 Likelihood Ratio Test

\begin{tabular}{|l|c|c|c|c|}
\hline \multicolumn{1}{|c|}{ Model } & -2 Log Likelihood & Chi-Square & df & Sig. \\
\hline Intercept Only & 21,149 & & & \\
\hline Final & 8,726 & 12,424 & 2 & .002 \\
\hline
\end{tabular}

Source: Results of SPSS test, 2018.

The test results (see Table.2) showed that the final significance value of 0.002 . The final model's significance is the value at which the independent variables are tested with the dependent variable simultaneously and seen whether or not it exerts influence. It shows that there are influences of independent variables, namely work environment variables and work stress on the dependent variable, namely work satisfaction variable, because the significance of the final model is $0.002<0.05$. Based on the predetermined hypothesis, the work environment, and work stress influence the work satisfaction of medical record officers in X Hospital so that the work environment and work stress together simultaneously influence the work satisfaction of medical record officers.

One of the best solutions to this problem is improving working environment conditions. It can give officers employment satisfaction so that they can improve the work performance of medical record officers at X Hospital. The research conducted by (Siallagan, 2014) supports this result that environment work tends to be increased to be better, and the role of superiors in reducing work stress has an effect on increasing satisfaction employee work to improve employee performance. Furthermore, (Faragher et al., 2013) also stated that the work environment correlates with stress levels and together can have a significant impact on work satisfaction.

Moreover, to determine the opportunity value between each independent variable with the dependent variable, it is necessary to calculate the odds ratio. Stages are looking for is knowing the odds ratio estimates the value of the ordinal logistic regression test partially, namely determine the effect of each independent variable on the dependent variable. The result of partial ordinal logistic regression can be observed by looking at the following table results: 
Table 3. The Parameter Estimates Table

\begin{tabular}{|c|c|c|c|c|}
\hline Variable & Estimate & Wald & df & Sig. \\
\hline Work environment & 2,268 & 3,892 & 1 & .049 \\
\hline Stress_Work & 3,561 & 5.492 & 1 & .019 \\
\hline
\end{tabular}

Source: Results of SPSS test, 2018.

The test results are presented in Table 3 shows that the significant working environment variable value is 0.049 . The variable working environment has significance $<0$, 05, which means that the work environment significantly influences work satisfaction. It is supported by (OLDEMAR, 2015), which stated that the work environment could affect employee work satisfaction.

Sohail et al. (Sohail et al., 2014) stated that complete amenities consist of a table, chair, and tool office stationery supplies that can support environment work at 54\% and affect job satisfaction. Safe Work Australia (Safe Work Australia, 2011) states that settings amenities excellent working could cause plot work employees to be smooth so that implementation work to be more productive. Variable uses the value as the significance of occupational stress of 0.019. Variable workplace stress has a significance $<0,05$, which means that work stress affects work satisfaction significantly. It is supported by (Latifa Hanim, 2016), which states that work stress can substantially influence employee work satisfaction. Sharpe (Sharpe \& Johnson, 2002) said that job by the boss who doesn't correspond with job description would cause chaos in implementation work, so that arise stressed-out work on employees that affect job satisfaction. The action corrective needed for stressed-out fix work is with fix demands task that is the second job with add power work new with appropriate qualification education with description work for productivity work increase (Hoboubi et al., 2017).

If the ordinal logistic regression model has been tested and its value significantly partially significant effect, so the data can be interpreted using the odds ratio test by looking at the following table results:

Table.4 The Parameter Estimates Table for Odd Ratio Value

\begin{tabular}{|l|l|c|c|c|}
\hline \multicolumn{2}{|c|}{ information } & Estimate & Exp () & Sig. \\
\hline Location & Work environment & 2.268 & 9,660061 & .049 \\
\cline { 2 - 5 } & Stress_Work & 3.561 & 35,19838 & .019 \\
\hline
\end{tabular}

Source: Results of SPSS test, 2018

Table.4 showed that the $\operatorname{Exp}()$ is the odds ratio. The odds ratio value indicated that the medical record staff who have the right work environment could increase the level of work satisfaction by 9.66 times compared to medical record officers who have a poor work environment. On the other hand, the medical record staff with no work stress can increase work satisfaction by 35.19 times compared to medical record officers who have work stress.

Based on the odds ratio value, we can conclude that these results can be used as a reference for management in describing the conditions of the work environment and work 
stress, which have an impact on increasing the level of work satisfaction of medical record officers at the "X" Hospital. Andrade (Andrade, 2015) states that the logistic regression analysis's odds ratios are used to present a more accurate picture of the opportunities in terms of the independent variable on the dependent variable.

The result of the logistic regression test shows how much the independent variable (work environment and work stress) can explain work satisfaction. It can be seen from the Pseudo R-Square value shown in the following table.5:

Table.5 The Pseudo R-Square (Coefficient of Determination)

\begin{tabular}{|l|l|}
\hline Pseudo R-Square & .615 \\
\hline Cox and Snell & .700 \\
\hline Nagelkerke & .452 \\
\hline McFadden & \\
\hline
\end{tabular}

Source: Results of SPSS test, 2018.

Table. 5 showed that the estimated value of determination uses the Nagelkerke value is 0.700 or $70 \%$. It means that the independent variable (work environment and work stress) that can explain work satisfaction by $70 \%$. In comparison, the remaining $30 \%$ is explained by other variables outside the model that are not examined. So, these results conclude that the work environment and work stress variables provide a comprehensive explanation for the work satisfaction of medical record officers at X Hospital. The clarity of the explanation reaches $70 \%$, and the other variables not examined by researchers can only explain work satisfaction by $30 \%$, less than the work environment, and work stress. (Sinambela et al., 2014) told that the coefficient of determination is an indicator used to describe the variables studied in the study compared to variables not examined.

\section{CONCLUSION}

The result concludes that the work environment and work stress influence the work satisfaction of medical record officers at the X Hospital. The research recommends the head of medical record officer should have to make an excellent functional workspace for medical record officers and additional the facilities such as automatic queue numbers, stairs, photocopying machines, guidelines for the implementation of Hospital Information System and the addition of officers to avoid double jobs and double shifts.

\section{REFERENCE}

Aliga, R. (2015). Pengaruh Gaya Kepemimpinan, Motivasi dan Disiplin Kerja terhadap Kinerja Pegawai Badan Diklat dan Litbang Pemerintah daerah Kabupaten Sragen. http://eprints.ums.ac.id/37384/13/NASKAH PUBLIKASI..pdf

Andrade, C. (2015). Understanding relative risk, odds ratio, and related terms: As simple as it can get. Journal of Clinical Psychiatry, 76(7), e857-e861. https://doi.org/10.4088/JCP.15f10150

Aruan, Q. S., \& Fakhri, M. (2015). Kerja Karyawan Lapangan Departemen Grasberg Power Distribution Pt . Freeport Indonesia. Modus, 27(2), 141-162. https://ojs.uajy.ac.id/index.php/modus/article/download/553/579

Chairizal, T. N., Ningsih, D. S., \& Nuryanti. (2014). Pengaruh Stres dan Kepuasan Kerja 
terhadap Kinerja Perawat Rumah Sakit Ibu dan Anak Eria Bunda Pekanbaru. JOM FEKON, 1(2), 17. https://jom.unri.ac.id/index.php/JOMFEKON/article/view/5440

Faragher, E. B., Cass, M., \& Cooper, C. L. (2013). The Relationship between Job Satisfaction and Health: A Meta-Analysis. From Stress to Wellbeing, 1. https://doi.org/https://doi.org/10.1057/9781137310651_12

Hapsari, A. T. (2017). Pengaruh Stres Kerja Terhadap Kepuasan Kerja Karyawan PT. Pos Indonesia (Persero) Mail Processing Center Bandung [Universitas Widyatama]. https://repository.widyatama.ac.id/xmlui/handle/123456789/8803

Hoboubi, N., Choobineh, A., Kamari Ghanavati, F., Keshavarzi, S., \& Akbar Hosseini, A. (2017). The Impact of Job Stress and Job Satisfaction on Workforce Productivity in an Iranian Petrochemical Industry. Safety and Health at Work, 8(1), 67-71. https://doi.org/10.1016/j.shaw.2016.07.002

INDONESIA, R. (2009). UNDANG-UNDANG REPUBLIK INDONESIA NOMOR 36 TAHUN 2009.

Indonesia.

https://jdih.kemenkeu.go.id/fullText/2009/36TAHUN2009UU.htm

Itika, J. S. (2011). Fundamentals of Human Resource Management. In African Public Administration and Management series, (2nd ed.). University of Groningen / Mzumbe University. https://openaccess.leidenuniv.nl

Laksmini, P. A., Darmayanti, N. L., Alfred, V., Mulana, S., Studi, P., \& Informasi, M. (2019). Analisis Faktor-Faktor Kepuasan Kerja Terhadap Jalan Di Rumah Sakit Bhayangkara Denpasar Program Studi Manajemen Informasi Kesehatan, Institut Ilmu Kesehatan Medika Persada tentang perawatan dan pengobatan yang dilakukan tindakan medik menjadi lama . pen. BALI HEALTH JOURNAL, 3(April). http://ejournal.iikmpbali.ac.id/index.php/BHJ/article/view/41/21

LATIFA HANIM, M. (2016). Pengaruh Stres Kerja Terhadap Kepuasan Kerja Serta Dampaknya Pada Kinerja Karyawan Hull Construction Di Pt. Dok Dan Perkapalan Surabaya. Jurnal Ilmu Manajemen (JIM), 4(3), 1-10. https://jurnalmahasiswa.unesa.ac.id/index.php/jim/article/view/17212/15651

Mangkunegara, A. P. (2014). Manajemen Sumber Daya Manusia Perusahaan. Rosda.

Menteri Kesehatan Republik Indonesia. (2002). Keputusan Menteri Kesehatan Republik Indonesia Nomor 1405/MENKES/SK/XI/2002. https://www.gbcindonesia.org/download/doc_download/41-kepmenkes-no-1405tahun-2002

OLDEMAR. (2015). Pengaruh Lingkungan Kerja Terhadap Kepuasan Kerja Perawat Rumah Sakit Syafira Pekanbaru. Jom FISIP, 2(2), 1-8. https://jom.unri.ac.id/index.php/JOMFSIP/article/view/5321/5200

Organisation for Economic Co-operation and Development (OECD). (2012). Sick on the Job? Myths and Realities about Mental Health and Work. In OECD Publishing. https://doi.org/10.1787/9789264124523-en

Pormiki. (2010). Pedoman Penyelenggaraan Rekam Medis Dan Informasi Kesehatan Di RS. Kementrian Kesehatan.

Robbins, S. P., \& Judge, T. A. (2014). Perilaku Organisasi (16th ed.). Salemba Empat.

Rut Manggiasih, H. P. S. (2014). Analisis Lingkungan Kerja dan Stres Kerja Dampaknya 
Terhadap Kinerja Karyawan (Studi Kasus di RSUD). Jurnal Ilmiah Manajemen Bisnis, 14(1),

http://ejournal.ukrida.ac.id/ojs/index.php/IMB/article/download/864/853/

Safe Work Australia. (2011). MANAGING THE WORK Code of Practice. https://www.safeworkaustralia.gov.au/system/files/documents/1702/managing_work_ environment_and_facilities2.pdf

Sharpe, D., \& Johnson, E. (2002). Chapter 3: Managing Conflict with Your Boss The Look of Conflict (p. 9). Center for Creative Leadership (C) http://uthscsa.edu/gme/documents/ManagingConflictwithYourBoss.pdf

Shukla, S., Adhikari, B., \& Ray, M. (2016). Emotional Intelligence and Job Satisfaction: An Empirical Investigation. Amity Global HRM Review. https://www.researchgate.net/publication/322976907_Emotional_Intelligence_and_Jo b_Satisfaction_An_Empirical_Investigation

Siallagan, R. (2014). Pengaruh Lingkungan Kerja dan Stres Kerja Terhadap Kepuasan Kerja Karyawan pada PTPN VII (Persero) Unit Usaha Pematang Kiwah [Universitas Lampung]. http://digilib.unila.ac.id/4332/

Sinambela, S. D., Ariswoyo, S., \& Sitepu, H. R. (2014). Menentukan Koefisien Determinasi Antara Estimasi M dengan Type Welsch dengan Least Trimmed Square dalam Data yang Mempunyai Pencilan. Saintia Matematika, 02(03), 225-235. https://media.neliti.com/media/publications/221435-none.pdf

Singh, T., Chetty, N., \& Karodia, A. M. (2016). An Investigation into the Impact of Absenteeism on the Organisational Performance of a Private Security Company in Durban , Kwazulu-Natal. Singaporean Journal of Business Economics and Management Studies, 4(11), 105-159. https://doi.org/10.12816/0027227

Sohail, M. M., Naeem, F., Azhar, Z., Khan, S. H., \& Parveen, S. (2014). Impact of Office Facilities and Workplace Milieu on Employees' Performance: A Case Study of Sargodha University. Asian Journal of Empirical Research, 2(4), 96-117. http://www.aessweb.com/pdf-files/96-117.pdf

Yulianto, Y., Robihaningrum, N., \& Elinda, B. D. (2019). Management Multivariate Analysis Methods for Variables Measurement in Scientific Papers. Aptisi Transactions on Management (ATM), 3(1), 65-72. https://doi.org/10.33050/atm.v3i1.826 